\title{
Social Representations of Medically Assisted Fecundation a Study on the Discursive Construction of "Media Texts"
}

\author{
Amelia Manuti, Giuseppe Mininni \\ Department of Psychology, University of Bari, Bari, Italy. \\ Email: a.manuti@psico.uniba.it \\ Received June 29 $9^{\text {th }}, 2010$; revised July $3^{\text {rd }}, 2010$; accepted July $5^{\text {th }}, 2010$.
}

\begin{abstract}
The present contribution moves from the theory of social representations (Moscovici, 1961) and focuses attention on the importance of social communication within negotiation processes of shared meanings. Actually, discursive psychology (Potter, \& Wetherell, 1987; Billig, 1991) has showed that social representation have a narrative nature since they organize the cognitive schemata that people use to give sense to the world (Lazlo, 1997). In such a frame a crucial role is played by mass media, which do contribute to construct and convey the figurative nucleus of each representation (Mininni, 2004). By adopting this discursive perspective, the present contribution aims at investigating the social debate about assisted fecundation which in Italy has accompanied the campaign for the abrogation of Law 40. The corpus of data is made up of a sample of 46 media-texts collected within the weeks before the referendum. The data have been investigated by adopting diatextual analysis (Mininni, 1992; 2003; 2005).
\end{abstract}

Keywords: Media Discourse, Ethical Dilemmas, Discourse Analysis

\section{Introduction}

The construct of "social representation" is ambivalent, since, for instance, what for its critics is a limitation, that is its vagueness (Jahoda 1988; Potter e Litton 1985), for its supporters is meant as a merit, that is its openness and versatility (Duveen \& Lloyd, 1990; Allansdottir, Jovchelovitch \& Shathopoulou 1993; Voelklein \& Horwath, 2005). Actually, the theory of social representation has paved the way for many research traditions as well as debates and polemics. In view of the above, it is worth asking "why it is so difficult to understand it" (Raudsepp, 2005). At the end of her analysis, the researcher acknowledges that: "the theory of social representations is appropriate for research questions that concern communicative processes within groups that are related to the cognitive-emotional construction of reality, or that concern the use of Social Representations in intergroup processes and intra-individual processes for constructing social identities" (Raudsepp, 2005: 466).

Nonetheless, apart from any contraposition, the theory of social representation has gained sufficient agreement within the literature as to allow the integration with other research perspectives within social psychology and psychology of communication (Rose et al., 1995).

The aim of the present contribution is to conjugate the theory with the rationale of discursive psychology (Harré \& Gillett 1994; Mininni 1995) and more specifically with a psychosemiotic perspective (Lloyd \& Duveen, 1990) which is better specified through the adoption of diatextual methodology (Mininni, 1992; 2003).

The object of the investigation is the process of sense-making which has engaged individuals on occasion of the referendum for the abrogation of law 40 on assisted fecundation. On the $12^{\text {th }}$ and on the $13^{\text {th }}$ of June 2005 Italians have been called to express their opinion on 4 questions about the different articles of a law which had been previously approved by the Parliament as to rule the bio-medical techniques aimed at promoting fecundation. The bio-ethical issues brought about by the law and by the consequent referendum engage people in translating a political choice into a number of beliefs which have a dilemmatic origin. The special complexity of the social representations which will be investigated is linked to the process of production and diffusion which take place on the borders of different "discursive spheres" (Volli, 2005), that is those enunciative places, where regimes of social participation are determined and where categories of "questionable issues" are defined and discussed, thus shaping and organizing actual "idiomatic scripts", both in terms of lexical and grammatical options as well as in terms of interaction styles. The diatexts of the biomedical issues show the role that some social representations play within a community, as they allow people to develop points of view on very complex questions and engage them in finding consensus, though fully respecting differences in enunciative positions and value attributions.

\section{The Semiotic Nature of SR}

The theory of social representations shows the variety of enunciative positions which people could assume upon socially relevant issues within a specific cultural frame. Alone the theory cannot explain neither why people adopt different social representations nor the processes of construction/generation of these "unities of the semiosphere". This notion, proposed by Lotman (1985), highlights all the resources (cognitive as well as emotive) which can be used within the communicative practices of a specific semiotic subject (groups, societies, cultures). Being "components" of the semiosphere, social representations express also the enunciative dynamic of positions that groups (and individuals) may display in the "fight for meaning", 
generally qualified as "power".

Actually, social representations are more than just social psychological tools orienting the understanding of the world people live in. In supporting particular versions of social order, they protect the interests of specific groups over others. Hegemonic representations pervade the dominant social construction of reality while oppositional representations contest these versions. However, although consensual realities do not exist in society, a certain degree of consensus exists in specific areas of the representational field, which are in permanent interaction with more mobile and unstable elements. Then, consensus is the outcome of power struggles occurring in the social arena. Actually, since everyday life is marked by competing versions of reality and power relations, specific social groups have more access than others to the means for establishing dominant meanings in the public sphere. Moreover, the location of social representations in institutional settings, such as in the mass media, stabilise, control and even segregate social groups and individuals, thus establishing the representational field where people take up their (often contradictory) positions. Social representations arise from these contradictions and it is their very meaning that the theory attempts to understand.

\section{Towards a Dialogical Epistemology of SR}

The concept of social representation is multifaceted. On the one hand, social representation is conceived as a social process of communication and discourse, in the course of which meanings and social objects are generated and conveyed. On the other hand, SR are seen as individual attributes, as individual structures of knowledge, symbols and affect which are shared with other people in a group or in the society (Moscovici, 1961).

This dual view of the concept makes it versatile and gives rise to various interpretations and uses which are not always compatible with each other (Allansdottir, Jovchelovitch, \& Stathopoulou, 1993). Its versatility stems a particular openness of the theory which makes it possible to be appropriated by other approaches within social psychology. Part of this problem results from an unfinished discussion about the epistemological aspects of social representation theory (Wagner, 1995; Markova, 2000; Duveen, 2001). Actually, the key to the problematic character of SR theory can be found in their nature, which encompasses both cognitive operational systems (i.e. processes of categorization, selection, association, stereotyping and attribution) as well as interpretative rules. Traditionally, social psychology studied these two systems are separated from each other since the first is the privileged target of mainstream social psychology, while the second are mostly approached by phenomenologically- oriented research.

Nonetheless, the bridge between the levels of representations is social communication, which not only transmits but also shapes representations and makes them socially shared. Actually, SR theory is based on two assumptions. First, that the social world is constructed through the thoughts and concerted interactions of a group, society or culture (Breakwell, 1993), and, second, that this social world is constructed through and thanks to discursive practices (Wagner, 1998). Moreover, by transforming Durkheim's notion of collective representations (1898) into the concept of SR, Moscovici explicitly assumed the plural nature of social knowledge, that is "the coexistence of competing and sometimes contradictory versions of reality in one and the same community, cultural and individual" (Voelklein \& Horwarth, 2005: 5). Therefore, SR "provide people with a code for social exchange and a code for naming and classifying unambiguously the various aspects of their world and their individual and group history" (Moscovici, 1973: 17). At one level, SR are cognitive structures which function to facilitate communication between members of a collectivity because of their shared or consensual form. For the individual, their role is to give novel experiences (people, objects or events) meaning by setting them in a contextual frame that makes them familiar. At another level, SR are public rhetoric used by groups to engender cohesiveness to other groups.

Nonetheless, a representation is not a mere reflection or reproduction of some external reality. There is a symbolic space in the development and negotiation of representations, which is why all social actors hold creative power and agency in their formation and use. Such emphasis on the dialectical and dialogical nature of social knowledge is also found in the notion of cognitive polyphasia (Moscovici, 1961), that is the coexistence within a social group of different and often incompatible cognitive styles and forms of knowledge employed by one and the same individual (Horwarth, Forster, \& Dorrer, 2004; Jovchelovitch, 2002; Wagner, Duveen, Verma, \& Themel, 2000). Depending on the social and cultural settings prevalent at a particular time, human being can draw on conflicting representations. In this sense, cognitive polyphasia refer to the possibility that different kind of knowledge, inspired by different rationalities, may "live side by side in the same individual or collective" (Jovchelovitch, 2002: 124). As a result, traditional and modern representations confront rather than replace each other.

Social representations are therefore not only a product of human agents acting upon their society but are equally prescriptive and coercive in nature. They become part of the collective consciousness, especially once they are "fossilised in tradition and taken for granted in social practice" (Moscovici, 1984: 13). Yet, this does not mean that social representations cannot be challenged or changed: as well as they are created by human beings they can be modified by them.

Recently, the evidence of such a kaleidoscopic and intersubjective nature of SR has lead to a re-interpretation of the concept in terms of sensitising rather than definitive (Liu, 2004). This turn derives from a different interpretation of natural sciences and social sciences in terms of monological and dialogical epistemologies (Potter \& Wetherell, 1999; Markova, 2000; 2003). Natural sciences are monological because they are concerned with reified and voiceless objects. They analyse things in terms of what they are and define them in their entirety and completeness. In contrast, humanities and social sciences are dialogical since they are concerned with multifaceted and multi-voiced human minds and languages which are fundamentally reflexive and historically, culturally and socially embedded (Duveen, 2007). The aim of humanities and social sciences is then to understand and interpret the dynamics of the social world.

This assumption and the consequent recasting of SR in terms of dialogical and sensitising concept entail both theoretical and methodological implications. Theoretically, they help to clarify some of the critical confusion regarding the vagueness and 
versatility of the concept without scarifying the openness of the theory. Methodologically speaking, they highlight the importance of the study of SR from the actors' point of view. SR as a form of social knowledge which is held by social actors cannot be detached from the knowledge of social actors and of their symbolic world. SR would have little meaning if they are set apart from the ways in which social actors elaborate and communicate their life-world. In this sense, the point of departure for the study of SR is not their components and structures supposed by the researchers but the life-world of social actors and their symbolic communication (Lazlo, 1997).

\section{Themata as Cognitive core of Social Representations}

One of the key features of the theory of SR is its being "a scientific analysis of what is commonly called common sense" (Moscovici, 1973: IX). In this light, the function of SR is mostly evident in the changing modern world as people form shared common sense concepts trying to disentangle and become accustomed with things that are new and unknown (Moscovici, 1981). Similarly to the myths of traditional societies SR form systems of values and beliefs providing people with a common code for communication (Moscovici, 2001; Wagner et al. 1999).

A social representation consists of a rather stable central element and more peripheral changeable elements. It has been suggested that each social representation has a stable central core (Abric, 1984; 2001), an organizing principle (Doise, 1984), a hard core (Mugny \& Carugati, 1989) which creates and organizes the social representation. Around the central core, central themata are organized (Liu, 2004; Markova, 2000; Moscovici, 2001), that is "primary conceptions or preconceptions" (Moscovici \& Vignaux, 2000: 177) which may take the form of beliefs (the American dream), maxims (we are what we eat) and social definitions (psychoanalysis is a confession).

Moscovici (1989) explicitly introduced the concept of themata in SR theory in order to understand the genesis and structure of SR and to investigate their relationship with communication. In this light, themata are the prototypes of commonsense knowledge. Some themata may exist implicitly in commonsense and may never be brought to the explicit attention of social thinking while some other themata may be foregrounded in public discourse and thus come to operate as source ideas for SR and communication (Moscovici \& Vignaux, 2000).

According to Moscovici (1989) the structured contents and the genesis of SR are interdependent. This interdependence is linked with themata: the structured contents of SR rest on an "initial string of few themata which appear to have a generative as well as a normative power in the formation of a representation" (Moscovici: 2001: 30-31).

In this sense, themata are the deep structure of a social representation. It is a generative structure and acts as the organizing principle of the whole representation. In this sense, the concept of themata is similar to the notion of central core in Abric (1988). Nonetheless, a themata is generally an antitheticcal couple in which the two components of the couple are dialectically interdependent (i.e. fullness/emptiness). Secondly, the concept of themata focuses explicitly on the dialogical nature of SR and communication. It implicates the dynamics of social knowledge which is inbuilt in culture and history and transformed and maintained through discourse.
In the light of the concept of themata SR are not an organized mass but a polymorphous construction. Therefore, themata refer to historically embedded presuppositions, culturally shared antinomies and the deeper logic of social thought, which manifest themselves pragmatically through language and communication.

In accepting the concept of themata a question arises concerning how a representation is socially shared and communicated by the members of a group, society, culture. Moscovici (1988) distinguishes three ways in which SR can be shared. They can be hegemonic, namely they are shared by all members of a society and thought unquestionable; they can be emancipated, with a certain degree of autonomy with respect to the interacting segments of society and they can be polemical, held only by some groups in society while other groups may hold opposite views.

According to Moscovici (1988) these three ways are independent, differently in terms of the concept of themata a social representation may involve simultaneously these three different ways of sharing in a complementary manner (Liu, 2004). This interweaving process between different ways of sharing SR is mostly evident with reference to mass media communication.

\section{Diatexts as Discursive Mode of Social Representations}

The notion of social representation foregrounds the cognitive and interactive nature of the processes which is willing to investigate, leaving in the background any reference to their fundamental semiotic and communicative dimension, which is explicitly recalled by researchers (starting form Moscovici). A different emphasis on such dimension is cast both on the notion of "interpretative repertoires" (Potter \& Wetherell,1987) as well as on the notion of "diatexts" (Mininni, 1992; 2003).

The discursive turn of British social psychology has distinguished it self in criticizing the theory of social representation (see for instance among others: Billig 1991). The most relevant result is the proposal to overcome the theory of social representation and to substitute it with the construct of "interpretative repertoires". The main advantages of such option derive from the focus on the communicative nature of what might be believed by a social group on a specific social object. The "interpretative repertoires", as well as (or, better, more than) social representations show that what social groups know about reality is the temporary result of their encounters and negotiations.

The construct of "diatext" is sympathetic with the conception according to which "human beings do use language rather are language" (Volli, 2005). The linguistic (or better semiotic) texture of each human phenomenon (starting from the self) derives from the fact that "within everything man does and possesses, there is language" (Hegel, 1968: 8). The notion of "diatext" recalls:

The dynamic of the relation text-context as sense making generative procedure;

The dialogic of positions expressed by the dialectic between "logoi" and "antilogoi" which is inherent to each enunciative operations;

The necessity to anchor subjects to the "text" meant as an enunciative form of coherence, responsibility and signification.

Such notion becomes mostly explicit within the discursive and cultural turn in psychology, since it is coherent with the socio-constructionist theories which generally inspire it (Duveen, 
1999). Everything that people (and communities) might consider as psychologically pertinent is constructed thanks to the (dia)texts of their interactions.

A very useful specification of the cultural constructive role played by language is given by the concept of "discursive sphere". Actually, discourse - meant as "language between men" (Volli, 2005: 69) — acts within "very peculiar spaces of existence" (ibidem), which could be tangible and concrete (as for instance a class for the discursive sphere "education") as well as abstract (as for instance a chat room for the discursive sphere of "virtual communication"). A discursive sphere allows framing the several types of relations which connect people to specific enunciative contexts. This is a very general notion, since it limits it self to highlight that the relationship between people and their own discursive activities is circumscribable (actually within a "sphere"), that is it could be thought as a space of enunciation of sense. The "universes of discourse", that is the worlds created within the process of activation of sign systems are to be distinguished according to a unfinished list of coordinates, so that the discursive sphere could be "public vs private", "open vs closed", "focused on word vs focused on image", "devoted to decision vs devoted to knowledge", "serious vs entertaining", and so on (Volli, 2005: $85)$.

The social representations of "medically assisted procreation", analysed in the present contribution through the diatextual approach, are shaped within a complex intrigue of discursive spheres since:

1. The generative horizon of positions is political in nature and refers to "unquestionable issues", as notoriously are those posed by bioethics, which unavoidably engage human minds with moral dilemma;

2. The debated topics object of social representation do refer to the "private discursive sphere", since they recall positions which highlight personal identity, as for instance sexual preferences, religious options, etc.

3. The reference contexts within the process of text production are defined in terms of mediated interaction. Actually, the presence of the media shapes the "public discursive sphere" by transforming it into a regime of "quasi-interaction" often characterized by "para-social modalities".

\section{Diatexts of Private Worlds through Mass Media}

The discursive process essential to the formation and functioning of SR occur both at the inter-individual level and the level of mass media (Mininni, 2004). The mass media very rapidly disseminate knowledge and other information to the public creating homogeneous images in a relatively short time period when compared with inter-individual communication. Also, the mass media are the most prolific means of information dissemination, a mediator between scientific and social knowledge, and more often than not the first to communicate new information to the public thereby setting the agenda for further discursive processes in society (McCombs \& Shaw, 1972; McCombs, Shaw, \& Weaver, 1997). In this perspective SR are "discursive contexts", generally used by the speakers to make sense and to understand events, which could be also strategically adopted by the media to shape SR and to orient social action (Wagner et al., 1999). This is the case of public campaigns concerning ethical issues and/or socially desirable be- haviour, such as for instance organ donation and transplantation (Moloney, Hall, \& Walker, 2005; Moloney \& Walker, 2000) and new foods (Houtilainen \& Tuorila, 2005) or genetically modified organisms (Castro \& Gomes, 2005).

\section{The Study: Aims, Sample and Methodology}

The discursive nature of social representations highlighted by the diatextual approach is particularly evident when giving voice to the "cognitive polyphasia" of social groups (Moscovici, 1961; Jovchelovitch, 2002; Wagner, Duveen, Verma, \& Themel, 2000; Cavazza 2005), they intercept the level of "public opin- ion". As well known, the construction of such level of self rep- resentation of society is the result of the profound economical and political transformations which have characterized moder- nity. What could be argued within the "public sphere", aspiring to the agreement with the majority of communities' members, decides the "public opinion" relative to such issue. Starting from the diffusion of the press, the mass media have operated as powerful machines for the selection of social representations, as to elaborate and widespread "public opinion".

The discursive dimension of social representations has been investigated with reference to a very relevant Italian social issue that is the referendum campaign which has been carried out for the abrogation of Law 40 on assisted fecundation. Actually, this law has engendered heated debates pushing the public opinion to reflect both on the borders of scientific research (as for the experimentation on stamen embryonic cells) as well as on the meaning of responsible and ethic behaviour (as for the issue of artificial fecundation). The special complexity of the social representations object of analysis is linked to their being produced and diffused in a very uncertain format of "public opinion" at the interface of different "discursive spheres".

The value of human life, the mystery of the biological origin of the life of man and the sacred root of existence (as a unique experience of the self) are all traits which will push people to frame the object of their ideological confrontation within a private (intimate) discursive sphere. The function of science, the support of technique and the obligation to self care are, on the other hand, coordinates which engage people to put it necessarily within a public discursive sphere. The obligation to decide, the aspiration to the consent of the other and the will to overcome the other with any mean draw the possibility, for people, to meet and to discuss about this issue in a political discursive sphere. The claim to show the essentiality and the exemplarity of the "human case" and the run up of the exceptional (or of what is unusual) are the main features of the discussion about assisted procreation which takes place within a mediatic discursive sphere.

The corpus of data is made up of a sample of 46 texts that is all texts published on the topic of investigation by the national press and collected within the weeks before the referendum which took place on the $12^{\text {th }}$ and on $13^{\text {th }}$ of June 2005 . The texts have been collected both from two main Italian newspapers - Il Corriere della sera, a newspaper and La Repubblica, a left wing newspaper - as well as from two weekly magazines Famiglia Cristiana, a very popular catholic magazine and L'espresso, a popular moderate left wing magazine.

According to the epistemological assumptions of qualitative 
and hermeneutical analysis, the data have been investigated by adopting diatextual analysis (Mininni, 1992; 2003; 2005), that is a specific perspective within the frame of Critical Discourse Analysis (Van Dijk, 1993; 1997; 1998). The guiding principles for the diatextual researcher are dialogism, situationism and olism and all of them enhance the Gestalt nature of discourse. Though apparently evanescent, intangible, slippery, confused and impressionistic, the "oversummativity effects" of a particular discursive practice are the most interesting ones for the diatextual approach. Communicative events shape their sense through their being "texts" and, according to one of the most important Gestalt principles, the diatextual researcher respects the text so much that he refuses any systemic operation of cutting it in lower analysis units (words, phrases, paragraph, etc.), assuming that its meaning can be drawn only through a holistic attitude. Obviously, the analyst may focus on some segment of the "corpus", but his main interest is to enhance their contribution to the "spirit" of the text. Such a holistic approach is sustainable if the researcher is aware of his own fallibility and partiality. The diatextual scholar is cautious, since he knows that at any time he can fall into the abyss of over-interpretation. Anyway s/he starts from the assumption that the meaning of a discourse could be caught by answering three basic questions: Who is saying that? Why does he/she say it? How does he/se says it? These questions have an ethnomethodological valence since first of all they guide the practices of comprehension of those who participate to the communicative event. To come into a dialogical relationship means to grant such an enunciative contribution of sense, as to show who is speaking, what could legitimize what she/he is saying and which is its claim of validity. These questions organize interpretative procedures for a diatextual researcher, since they suggest that he/she looks for a series of markers which identify the Subjectivity, the Argumentation and the Modality of discourses and can thus catch the meaning within the dynamics of reciprocal co-construction of text and context of enunciation.

The first question (who is saying that?) aims at clarifying the complex construction of sense production which is part of every discourse and /or of every communicative event, because the text speaks of its subjects, thus revealing the complex nexus between the images the interlocutor has of him/herself and of his/her ideal addressee. The traits of subjectivity are recognizeable within discourse by diatextually looking at:

- Agency markers (i.e. active or passive grammatical formats etc.);

- Emotion markers (i.e. proximity, evaluation, specificity markers, etc.);

- Embrayage/Debrayage markers (i.e. the use of personal pronouns).

The second question (why does he/she say it?) identifies a dimension of semiotic relevance which allows discourse to "articulate motives", that is to organize the "meanings-why", to give voice to the objectives pursued by the interlocutor saying what he/she says. The traits of argumentation are revealed by diatextually looking at:

- Markers of "enjeu" (stakes, interests, etc.);

- Network of logoi/antilogoi, emerging from different narrative and argumentative programmes;

- Meta-discursive markers (attenuating markers, intensifiers, etc.).
The third question (how does he/she say it?) highlights the articulation of the "dictum" to the "modus" of discourse according to which the meaning is shaped acquiring a gestaltic nature which enables comparisons and evaluations like "good or bad", "beautiful or ugly", "efficient or inefficient" etc. The traits of discourse modality are diatextually recognizable through:

- Narrative markers (i.e. uncertainty, intentionality, coherence);

- Markers of discursive genre (i.e. epic, comic, tragic, romantic);

- Opacity markers (i.e. frame metaphors)

With reference to the purpose of this contribution, special attention has been paid to the communicative strategies used by the speakers and revealed by several pragmatic and linguistic cues (e.g. rhetorical figures, stylistic options, agentivity markers etc.). This option has finally allowed drawing a more general pathway of sense production known as the "semiotic square" (Greimas \& Courtes, 1979).

\section{Discussion of the Results}

The corpus of data is made up by 46 "media texts", that is articles published on the Italian national press on occasion of the campaign for the referendum for the abrogation of Law 40 on medically assisted fecundation.

These texts are a very vivid example of social communication campaign, aiming at constructing a totally different social representation of medically assisted fecundation. The debated object of the referendum poses very relevant ethical and religious issues which entail important personal and social implications.

\section{The Social Representation of the Beginning of Life: The Diatexts of the Embryo}

The analysis of the discursive data allows drawing a first basic distinction between a pro abrogation and an abstention position, though a wide range of different in-between and hybrid positions emerge.

The issue of assisted fecundation is discursively shaped as a relevant ethical dilemma, which engages identities into very complex and controversial debates, which start at an intrapersonal and manifest themselves at an interpersonal level through discourse. Such evidence is a common trait to all positions toward this issue (pro, contra and hybrid) and a further confirmation about the existence of a common symbolic field of representation (a core themata), which is but differently interpreted according to the social and cultural features of the interlocutors which give voice to any position.

Therefore, even if with the competing aim to impose one's own position as the most socially desirable one, similar rhetorical strategies are used.

For instance, all positions use popular and/or authoritative testimonials as to better ground the claim, to support their argument and to switch on one of the most famous weapon of persuasive communication that is social desirability (Cialdini, 1984). In other words, the social relevance of the issue "pushes" toward the adoption of a position which is congruent to what is expected most of the people would do. Then, the opinion manifested by some "others", which are perceived as trustworthy interlocutors (the voice of experts) or as most simi- 
lar to the self (as for age, gender, experience, etc.), becomes a mean to orient one's own opinion. In this case, the pro-position is sponsored by Sabrina Ferilli, a very well-known Italian actress (the voice of women), and by Prof. Umberto Veronesi, a popular researcher and past minister of health (the voice of science).

1. "The referendum on assisted fecundation will mark the future of many women. I vote Yes. Let us not miss your vote" (Sabrina Ferilli, Campaign for the abrogation - committee for the referendum - Yes to born, to heal to choose)

On the other hand, during the referendum, the contra position has been carried out by a special committee named "Science and Life- Allied for the future of man" which encompasses also very popular personalities from the world of religion, politics, science and entertainment. In this case, the slogan is:

2. "Life cannot be put to votes. Choose not to vote" (Umberto Veronesi, Campaign against the referendum - Life \& Science committee)

Both positions anchor their communicative strategies to an explicit personal positioning, since the arguments are constructed around the involvement of the testimonial: "On the 12th and 13th of June I [Sabrina Ferilli] vote yes" versus "I [Angelo Vescovi] do not vote".

Therefore, the enjeu of communication is constructed in terms of "identity". Discursively speaking, the emphasis put on identity manifests itself through the use of embrayage strategies, i.e. the explicit adoption of the enunciative reference to the "I" which is aimed at constructing a discursive ground in common with the interlocutor. Such option contributes to transform a mere debate between opposed slogans into a dialectical exchange of personal involvements ("I do not vote" vs "I vote Yes"). Nonetheless, the use of personal positions is strategically managed as to construct a subtle argumentative network, where to explicitly manifesting one's own orientation toward the issue becomes an attempt to impose to the public opinion:

3. "Actually are those who have doubts and perplexities sure about their intention to transform these doubts into prohibition for all, translating the "I will never do it" into "then nobody should be allowed to do it"? (Emma Bonino, Corriere della Sera 8-6-05, p. 8).

The nature of the texts analysed is profoundly argumentative. Therefore, their aim is not only to inform the readers about the law and about its implications but rather to convince the audience to actively take part to the debate by pragmatically manifesting their being pro or contra through vote or abstention.

To this purpose similarly to what happens in political communication (Cortini \& Manuti, 2002; Manuti, 2005) the discussion about law 40 is discursively constructed around an dialectic of positions we/they, which entails an implicit categorization in terms of what is to be considered good and what is judged as bad. In other words, the discussion is framed within the script of the communicative battle, since each interlocutor depicts his/her position as the most convincing and rational as compared to those of the others, thus considering superfluous any further argumentation.

4. "This law is so wrong that I think it is quite useless to explain why I vote four times yes" (Daria Bignardi, L'Espresso, 16/05/06: 31)

5. "Provocation is a specific juridical word, different from 'convocation'. In the case of elections the law calls us, therefore it is a duty to answer. The referendum is different. Some people (at the beginning 50.000 now 500.000) want to destroy a law that we have decided through our representatives. What they are asking us is to stay or not, they are provoking us. And we can destroy the law as they want or rather we can shield it by saying no. But we can also leave those 50.000 or 500.000 alone by refusing their provocation" (Giuseppe Anzani, Famiglia Cristiana num, 24: 3).

Moreover, such peculiar trait contributes to further highlight the contractual and dilemmatic nature of identity, which manifests itself through cognitive polyphasia (Moscovici, 1961), that is through the endless debate between personal and collective positions concretely shaped by the discursive cues. Indeed, the analysis of the data shows that the argumentative lexicon is very rich and articulated. It is mostly characterized by metadiscoursive cues (both textual and interpersonal) and argumentation auxiliaries (para-argumentative expressions and modalisation). Metadiscourse is the whole of all non propositional aspects of discourse aimed at facilitating the readers in organizing the content of communication coherently and in understanding the author's point of view by giving him/her credibility (Crismore, Markannen, \& Steffenson, 1993). More specifically, it could be distinguished into textual (i.e. logical connectives, frame markers, endophoric markers, evidentials, code glosses) and interpersonal (i.e. hedges, emphatics, attitude markers, person markers and relational markers. In this case, both corpora show the use of logical connectives (that is why), code glosses (for instance), attitude markers (I agree) and person markers (we).

6. "Today the supporters of the referendum aim at twisting law 40. Conversely, the committee science \& life wants to protect it and to let it be carried out. That is why it suggests to go not voting." (Committee Science \& Life, Allied for the future of man)

7. "Being an aged man, who has dealt with medical science and ideology I agree with the claims of the abrogation position. We should not forget all the disasters caused in the past by some behaviours of the church, as for instance when physicians were not allowed to examine women and consequently the lying-in women died" (Enzo Iannacci, L'Espresso, 16/06/05: 30)

The para-argumentative expressions are those expressions whose aim is to show their own arguments as convincing and self-evident as possible so that any further justification or ground becomes superfluous (i.e 'it is evident' in the following extract).

8. "I will vote Yes because it is evident that a liberalization of the modalities through which assisted fecundation is practiced and the progress of scientific research would be an advantage for the whole society" (Andrea De Carlo, L'Espresso, 16/05/05: 32)

The use of modalisation (i.e. 'rightly', 'perhaps', 'certainly') is aimed at discursively reducing to a minority those who support a position which is contrary to one's own by intensifying or by attenuating arguments.

9. "Among the most debated polemics of these days there is the issue of abstention, which refers to our declared conviction that on the $12^{\text {th }}$ and on the $13^{\text {th }}$ of June those who are willing to protect both women and newborns should abstain and perform all those good deeds which describe we as the believers. Actually, an active abstention is to be meant as efficient participation to the life of the country." (Famiglia Cristiana, 
23: 3)

Nonetheless, one of the most evident contrasts between the pro and contra positions is to be found in the discursive option which exploits the argument "I was an embryo too". The possibility to let the "voice of the embryo" be heard is differently framed within the discussion.

Actually, the political frame of the referendum has led the Italian public opinion and as a consequence mass media too to question themselves about "the identity of the human embryo and about the consequent ethical attitude" (Coda, Repubblica 13-06-05, p. 50). Then, the debate finds one of its highest vertex of dissonance in the interpretation of the ontological statute of the embryo: is it a "subject" or rather an "object", is it someone or is it something.

The pro-abrogation supporters define as "unheard" the claim to attribute human features to the embryo: the embryo is a form of life which does not have a voice, since it does not owe any enunciative modality of the self yet.

10. "The embryo is still an heap of few cells devoid of the cerebral line" (Rita Levi Montalcini, Corriere della Sera S 8-6-05, p. 9).

On the other hand, the abstention front claims to speak on behalf of the embryo, arguing the necessity to listen to those who are not able to let their voice and project of life to be heard.

11. "From a biological point of view, each of us is a human being since the fecundation that is since the encounter between the female ovules and the male spermatozoa. Before we did not exist. Since that moment I have been Angelo Vescovi, embryo, foetus, baby, child, boy, man. We should pay attention when we say that some beings might not be considered persons as the Romans behaved this way with the slaves. Moreover, we should pay attention when arguing that an embryo does not owe specific mental functions since an Alzheimer patient might experience the same situation, and I hope that nobody would ever think to eliminate him/her." (Famiglia Cristiana, 22: VII)

\section{Interpretative Repertoires of Social Participation: Fighting for Civilization or Defending the Law}

The referendum and consequently the social participation to this issue have been differently thematised with reference to the leading position which has inspired the debate. It is framed as a "battle for civilization" (Pannella, Repubblica , 10-6-05, p. 44) by those who are pro the abrogation or as "a defence of the law" (Campaign against the referendum - Life \& Science committee) by those who are against it.

Though such basic opposition, many other in-between positions emerge, thus signalling all the complexity of a debate which refers to very relevant ethical issues.

On the one hand, there is the hybrid position of those who, although acknowledging that "from an individual point of view it is right to think about the embryo as a person (...), do not understand why these conceptions should be imposed to those who have different ideas" (Berselli, Repubblica 10-6-05, p. 43). On the other hand, there is the stance of those who argue that to do not vote is the most responsible choice for those who are willing to oppose "a logic which is dangerous for all the human and moral fundamentals of our society" (Ruini, Corriere della Sera 31-5-05, p.3).

The analysis of such discursive positions allows catching the collision between the opposing representations and the com- peting discursive spheres (e.g. science vs. religion (morality), civic participation vs. abstention, trust vs. doubt in science, etc.) that exist in the context of well-established, socially legitimized symbolic subsystems (Sen \& Wagner, 2009).

Other prototypical examples of this contraposition are the following extracts.

12. "If embryos are sons and brothers, they have a mother and a father that is the spermatozoa and the ovules. Therefore masturbation would be the homicide of millions of possible parents" (Marco Pannella, Repubblica , 10-6-05, p. 44)

13. "Today, I am Angelo Scola, a man aged 64, because since my conception I have been that cell, that embryo. We should come back to the elementary human experience" (Cardinal of Venice, Repubblica. 10-6-05, p. 45).

The ideology which has inspired Law 40 considers the embryo as a human life, as a subject who has the same rights as those who have conceived it. The supporters of the abrogation highlight the "damages provoked by the metaphysics of the embryo" (Rodotà, Repubblica 13-5-05, p. 49) and deny to it "the right to become a person". The argumentation in juridical terms is based on the absolute lack of autonomy of the embryo: that project of life cannot be compared with an individual (the unique and authentic bearer of rights), "because to become an individual the embryo needs the welcoming into the body of a woman (...). Its life depends on the acceptance another life manifests" (Rodotà, Repubblica 13-5-05, p. 49).

The main inspiring motive of the abrogation position is to separate the interpretative repertoires/social representations of religion and science, of faith and politics. According to this position, it is necessary to distinguish the discursive sphere of biology, which attempts at catching the rhythms and the developmental procedures of embryos, from the discursive sphere of moral, which is oriented towards the philosophical theories and/or towards the religious beliefs, and engaged in enlighten the conceptual value of human beings:

14. "Science is doubtless able to define the stages of the development of the embryo and the gradual evolvement of the most important functions during the embryonic, foetal and neonatal life. Nonetheless, it is not able to indicate which is the relationship between the manifestation of such functions and the use of the concept of subject. The thesis of the manifestation of a subject since the moment of the fecundation of an ovule by a spermatozoon, is based not on scientific arguments but rather on moral, philosophical and theological arguments (...) upon which scientists have nothing to say as such" (Azzone, Repubblica. 17-5-05, p. 41)

15. "A liberal democracy cannot answer to an ethical question: if the human embryo is something or somebody" (Piero Ostellino, Corriere della Sera 4-6-05, p.1)

Therefore, although concerning a relevant public and social issue, this referendum has been mainly framed and interpreted as a socio-political battle between the catholic world and the laic and progressive world. Consequently, this opposition is mirrored into the discursive construction of social participation. The communicative strategies hint ironically to this context of discourse.

16. "On Sunday, do not forget to cross yourself. Your vote is important. On life, you cannot abstain" (Association Luca Coscioni. For a free scientific research)

17. "To abstain is not a sin" (Campaign against the referendum - Life \& Science committee) 
Extract n.16 shows the explicit intention to play with the double meaning of the verb to cross: both a ritual gesture which attests the participation to religious celebrations and the pragmatic act of voting. Both events take place on Sunday but refer to totally different behaviour and thus to different positioning strategies within the debate on artificial fecundation.

Similarly, extract $n .17$ which is drawn from the campaign against the referendum hints, at the religious world, by interpreting political behaviour according to the catholic script of sin/punishment/condemnation. This slogan aims at provoking the pro-position by attempting at the core meaning of the participation to the referendum, meant as both a civil right and duty. By highlighting that to abstain is not a sin, the contra position aims at reassuring the interlocutors about the implications of such a choice and thus at justifying them according to a shared code. Moreover, this slogan sounds ironic since the author is a catholic journal and hints at the meaning of the verb with reference to the sexual behaviour in polemic with the "self made ethic" of the pro position which is judged as irresponsible.

\section{The Discursive Dowels of the Social Representation}

The social representation of medically assisted fecundation which emerges from the media texts analysed is constructed around the pivots of law, scientific research, participation and civil rights. Nonetheless, though the thematic networks which embrace the representation of the issue are the same for the two main positions (pro and contra the abrogation) their discursive construction changes as long as the identity who gives voice to any stance changes.

The first example is the presentation of the object of discussion that is law 40 on assisted fecundation, which is described as unfair, cruel, medieval and unacceptable by the pro-abrogation supporters and as responsible and aware by those who invite to the abstention, explicitly condemning the referendum more than the law itself.

18. "Law 40 protects the health of women with gradual and non invasive interventions. It protects the life of the conceived by avoiding the overproduction of embryos, their selection and freezing. This referendum could only worsen things. I do not vote and you, who side you with?" (Campaign against the referendum - Life \& Science committee)

Another element of the representation which is differently interpreted is the meaning attached to the referendum itself. For those who are pro the abrogation, it is meant as an instrument of democracy, a mean to express freedom and liberty, while its discursive construction given by the contra abrogation position aims at presenting it as the attempt to make banal a very serious ethic issue.

19. "The instrument of the referendum is not adequate to intervene on complex issues, rather it risks to make banal them. Do not vote: a choice of awareness against a wrong referendum." (Campaign against the referendum - Life \& Science committee)

20. I will vote yes. It is shameful how much Italy kneels down before the Vatican. We live in a laic country, we live the new millennium and we do not burn witches anymore. This referendum is a very important date to understand if it does exist an actual laic, intelligent and tolerant Italy." (Luca Barbareschi, L'Espresso, 16-06-05: 30)

Another central theme is scientific research whose interpreta- tion is ambivalent. For the abrogation position research is interpreted as progress while for the abstention position it means respect of life.

21. "The $12^{\text {th }}$ and on the $13^{\text {th }}$ of June vote to affirm the progress of scientific research on the cure of serious and widespread illness" (Forum of Young Communist Women- Committee for the Referendum)

22. "Law 40 warrants a scientific research which fully respects life" (Campaign against the referendum - Life \& Science committee)

Similarly, the topic of research recalls the comparison with the other European countries as for the law on assisted fecundation. Therefore, for the abrogation position the referendum is an occasion to mark time with them while the abstention position highlights once more the importance to respect human dignity.

23. "If the referendum will succeed we will be able to compete with the other countries as for the research on the embryo stamen cells. We expect huge progress as for the cure of many degenerative illnesses. Finally we will end the awful page of Tourism of rights, since many couples have been forced to go abroad experiencing many obvious economical discriminations" (Carlo Flamigni, L'Espresso, 16-06-05: 33)

24. "Within the last years many European countries have promulgated laws as to run after science and medicine. Nonetheless, we should not forget that the European parliament has underlined the necessity to protect human life starting from the fecundation. According to the European Council both the embryo and the foetus should ever help the respect due to human dignity" (Famiglia Cristiana, 23: XV)

Therefore, fecundation is also a very important discursive node, meant both as a gift and as a choice. This thematic nucleus is strictly linked to the different subculture which frames discourses, that is ethics and science. According to the abstention position which interprets the debate about medically assisted fecundation as an ethical issue, fecundation is meant as a gift of life which has to be respected. Conversely, the pro-abrogation supporters argue their own position appealing to science and progress, thus interpreting fecundation as a way to affirm and manifest the self-determination of women. This aspect of the representation twists the role of women within the experience of fecundation: in the first case women are passive that is they almost undergone fecundation which is gift of God, differently according to the pro-abrogation women are active actors since they are allowed to choose and make decisions about their future.

25. "The actual right to have a son would be contrary to its own dignity and nature. A son is not something which is due and he/she cannot be considered as an object of propriety. Rather he/she is a gift, the most important gift of life" (Pope Benedetto XV, Famiglia Cristiana, 23: XVI)

26. "To vote Yes to the referendum means to erase the norms which place the rights of the newborn before those of the mother and deny the principle of self determination of the woman and the inviolability of the female body. This vote reaffirms the right to a free, desired and aware maternity." (Forum of Young Communist Women- Committee for the Referendum)

In this light, the participation to the referendum too acquires different shadings of meaning. For the pro-abrogation position it is interpreted as a civil and active responsibility, while for the abstention position "to abstain is not a sin".

27. "I will vote four times yes or better why not? I will go 
voting with the same spirit of the civil battles for the liberty to divorce and to abort" (Piero Chiambretti, L'Espresso, 16-06-05 p.32)

28. "To those who like us think that this law respects life, the right to embrace the most legitimate, aware and motivated choice: to abstain" (Famiglia Cristiana, n.23: 2)

Therefore, the analysis of the discursive construction of assisted fecundation reveals the existence of two different interpretative repertoires, which correspond to two subcultures: science and ethics.

On the one hand, the abrogation position interprets the referendum as an occasion to affirm a civil right and thus to actively take part to the life of the country, by manifesting one's own opinion on the future of the country. Actually, the pivot of the discussion is science, which should be free from any religious and political conditioning since it is the engine of progress and development. Citizens have the right and duty to manifest this awareness through the vote. As a consequence the most representative discursive act which emerges from those texts is to "awaken and sensitize civic conscience" by inviting to go voting.

29. "On the $12^{\text {th }}$ and $13^{\text {th }}$ of June vote yes four times to avoid that scientific progress stops in, to avoid that Italy looses rights and liberties, by humiliating the value of laicism, to allow the development of our country through debates about new issues which deals with the life of each of us and that will be even more important in the future of our society" (Committee for the referendum- 4 yes to born, to heal and to choose)

On the other hand, the abstention position constructs the question of assisted fecundation by discursively focusing on ethics. The object of discussion is presented as an unquestionable matter, since not everything which is scientifically possible is ethically legitimate. In this perspective, the referendum is presented as an inadequate and wrong instrument, because individuals cannot decide about such a complex and delicate question. Therefore, the most representative discursive act is to "boycott" the abrogation position by undermining its identity and by presenting its campaign as deceitful.

30. "The date with referendum is coming. The enjeu linked with the beginning of life is too high to trust to easy and synthetic slogans, which are unavoidable when forcing such a delicate and complex matter to the yes/no logic" (Famiglia Cristiana, n.22: I)

\section{The Discursive Construction of Identity: The Semiotic Square}

The traces of subjectivity, argumentation and modality highlighted in the texts have been organized according to a coherent profile, which has allowed the outlining of a more general pathway of sense production with special reference to the issue debated. To this purpose, the qualitative tool of the "semiotic square", i.e. the figurative representation of the logical articulation of any given semantic category (Greimas e Courtés, 1979), has been used to further investigate the media-texts collected. The focus of the analysis has been on the main argumentative patterns adopted by the speakers. These discursive data have been finally arranged according to four different identity profiles (or speaking positions) each following different interpretative schemata for medically assisted fecundation.

The main semantic oppositions which have emerged are those between "participation"/“abstention" and "general"/“particular" (cfr. Figure 1). These traits have revealed four positions toward medically assisted fecundation accounting for as many different discursive profiles which could be also differently interpreted in reference to the positions of the interlocutors

GENERAL

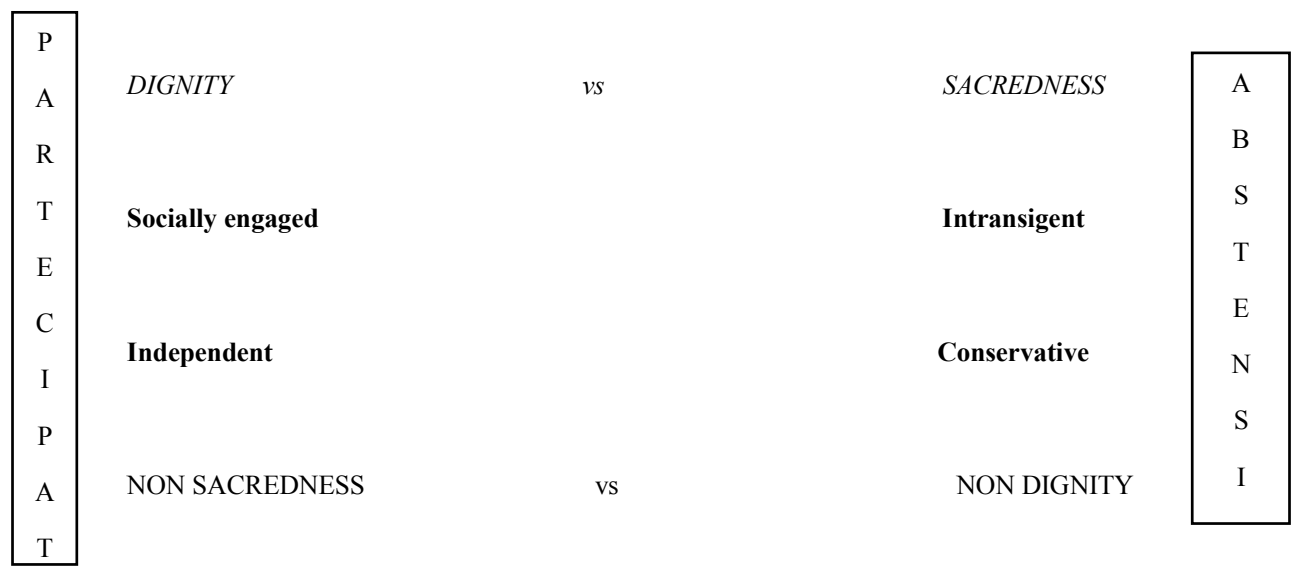

PAR T I C U LAR

Figure 1.

Semiotic square of the discursive positions on medically assisted fecundation. 
toward the issue.

According to the semiotic square, texts focusing on the categories of "participation" and "general" organize meanings which highlight an interpretation of the referendum as an important appointment in the social agenda to defend one's own civil rights. The identity profile which emerges is that of the "socially engaged" interlocutor, who is very active and always ready to get involved in social issues. He/she interprets social participation as an occasion to stand up for human rights and to let his/her voice to be heard no matter with reference to what kind of issue.

31. "I will vote yes four times, because this is a medieval, violent and offensive law. It invades our personal life with no respect at all" (Lella Costa, L'Espresso 16-06-05 p.32)

A second group of texts focus on the categories of "participation" and "particular". This discursive profile has been labelled "independent". It is characterized by interlocutors who openly declare themselves to be in favor of the abrogation by appealing to non sacredness of human life. Differently from the previous profile, the participation both to the social debate and to the political appointment of the referendum of the "independent" interlocutors is linked to the specific/particular features of the issue of assisted fecundation.

32. "Four yes against an unfair and contradictory law. To be on the side of life means to foster the birth of sons, the gift of maternity and fatherhood and this law makes it difficult" (Ilaria d'Amico, L'Espresso, 16/06/2005)

33. "I say yes because I cannot stand that the political majority or the Church may decide when and how we are allowed to have babies maybe also hindering us to do it" (Sabrina Ferilli, L'espresso, 16/06/2005)

The 'abstention' dimension pointed out as in opposition with participation mark other two discursive profiles. The first one, characterized by the association between "abstention" and "general", has been labeled as "intransigent". The interlocutors who express this position declare themselves against the abrogation and anchor their claim to the sacredness of life. This position is oriented toward a rigid defense of the values of the catholic culture. Similarly to the profile of the "socially engaged", who manifests his/her need to participate to social and political debates in general, the intransigent's contrastive behavior refers not only to this issue rather to all those position which may challenge a traditional asset of social, cultural and religious life.

34. "Life cannot be put to votes. I do not vote because I wish women's and babies' health to be protected" (Emanuela Lulli, Gynecologist, Campaign for the abstention - Science \& Life Committee)

Finally, the last discursive profile emerges from the intersecttion between "abstention" and "particular". This argumentative position, labeled "conservative", bases itself on the enhancement of the non-dignity of human life. It lies on the opposite pole of the "socially engaged" profile and similarly it is interested in defending a social and civil right which, in this case, refers to the choice of abstention. This position is also similar to the previous one, the intransigent, but differently it is a laic position. In common with the "independent" profile, the "conservative" anchor his/her position to the specific cultural and social frame of this event. But, while the independent discuss the choice of participation referring it specifically to the ethical issues raised by the debate on assisted fecundation, the choice for abstention which characterizes this profile leaves out of consideration the content of the referendum. Rather it opposes the manipulation that "those who have signed the abrogation issues" make of the referendum presented as an instrument of liberty to the public opinion, thus implicitly pushing to the exertion of this civil right.

35. "To abstain is a right. We mean the challenge of the referendum as a challenge of some reluctant people (those who have signed the abrogation issues) that we all have the right and in this case the civil pride to refuse." (Giuseppe Anzani, Magistrate, Interview in Famiglia Cristiana, 24: 2005)

\section{Concluding Remarks}

Social psychology, meant as action-research on the practices of humanization of personal and collective experience of life on earth, revises the main constructs of psychological exploration, starting from the self. The new interpretative horizons of subjectivities engage psychology in acquiring theoretical instruments as to cope with the complexity of processes and with the ambivalence of differences which do allow the reciprocal acknowledgement self/other. A route of "situational understanding" (Mantovani, 2005), congruent with such level of complexity is supplied by the linguistic and semiotic notion of "dia/text". In other words, people need texts: texts reveal who we are. Therefore, identities are constructed by "texts -ininteraction".

The corpus of media-texts analysed have showed the possible positions people (and their cultural communities) assume within the contestable narrative on the beginning of their life. Within the debate heated by the referendum the declarations "on behalf of the embryo" and "on support of knowledge and health" have derived their claim of validity by two opposed sub-cultures: that of "ethics" and that of "science". The discursive construction of such identity positions and thus of the social representation has answered to the inter-subjective dynamic aimed at deforming the expectations of reciprocal acknowledgement within the strategic practices of mis-acknowledgement. The inter-understanding process between individuals (and between communities) demands an agreement at least embryonic on the fact that any difference (of evaluation) in objecting the world do not legitimize neither hierarchical classifications nor solipsistic closures, rather trace an horizon of possibilities for multiple belongings and fluid identifications, which are own to our time.

\section{References}

Abric, J. (1984). A theoretical and experimental approach to the study of SR in a s situation of interaction. In R. Farr \& S. Moscovici (Eds), Social Representations (pp.169-184). Cambridge, England: Cambridge University Press.

Abric, J. (2001). A structural approach to social representations. In K. Deaux \& G. Philogene (Eds), Representations of the social: Bridging theoretical traditions (pp.42-47). England: Blackwell.

Allansdottir, A., Jovchelovitch, S., \& Stathopoulou, A. (1993). Social Representations: The versatility of a concept. Papers on social representations, 2, 3-10.

Billig, M. (1991). Ideologies and beliefs. London, England: Sage.

Breakwell, G. (1993). Social Representations and Social Identity. Papers on Social Representations, 2, 1-20.

Castro, P., \& Gomes, I. (2005). Genetically modified organisms in the 
Portuguese press: Thematization and anchoring. Journal for the Theory of Social Behaviour, 35, 1-17.

Cavazza, N. (2005). Atteggiamenti, rappresentazioni sociali e cambiamento: il ruolo della comunicazione, in G. Sarchielli e B. Zani (a cura di), Persone, gruppi e comunità. Scritti di psicologia sociale in onore di Augusto Palmonari (pp.163-182). Bologna, EmiliaRomagna: Il Mulino.

Cialdini, R. (1984). Influence. The Psychology of Persuasion. New York, NY: William Morrow e Company.

Cortini, M., \& Manuti, A. (2002). Il marketing politico sul web: Strategie discorsive di autopresentazione dei partiti politici italiani. In (a cura di) G. Mininni. Virtuale.com: la parola spiazzata (pp.123-155). Napoli, Campania: Idelson Gnocchi.

Crismore, A., Markannen, R., \& Steffenson, M. (1993). Metadiscourse in persuasive writing: A study of texts written in American and Finnish university students. Written Communication, 10, 39-71.

Doise, W. (1984). Social representations, intergroup experiments and levels of analysis. In R. Farr \& S. Moscovici (Eds.), Social Representations (pp.255-268). Cambridge, England: Cambridge University Press.

Duveen, G., \& Lloyd, B. (1990). Social representations and the development of knowledge. Cambridge: Cambridge University Press.

Duveen, G. (1998). The Psychosocial Production of Ideas: Social Representations and Psychologic. Culture \& Psychology, 4, 455-472.

Duveen, G. (2001). Representations, identities, resistance. In K. Deaux \& G. Philogène (Eds.), Representations of the social: Bridging theoretical traditions. (pp. 257-270). Malden Blackwell Publishing.

Duveen, G. (2007) Culture and social representations. In J.Valsiner \& A. Rosa (Eds.), The Cambridge handbook of socio-cultural psychology. (pp. 543-559). New York, NY: Cambridge University Press.

Greimas, A., \& Courtés, J. (1979). Dictionnaire raisonnée de Semiotique. Paris: Dunot.

Harré, R., \& Gillett, G. (1994). The discursive mind. London, England: Sage.

Horwarth, C., Foster, J., \& Dorrer, N. (2004). Exploring the potential of the theory of social representations in community based health research and viceversa. Journal of Health Psychology, 9, 229-243.

Houtilainen, A., \& Tourila, H. (2005). Social representation of new food has a stable structure based on suspicion and trust. Food and Quality Preference, 16: 565-572.

Jahoda, G. (1988). Critical notes and reflections on "social representations". European Journal of Social Psychology, 18, 195-209.

Jovchelovitch, S. (2002). Rethinking the diversity of knowledge. Cognitive polyphasia, belief and representation. Psychologie et Société, $5,121-138$.

Lazlo, J. (1997). Narrative Organization of Social Representations, Papers on Social Representations, 6, 155-172.

Lloyd, B., \& Duveen, G. (1990). A semiotic analysis of the development of social representations of gender. In G.Duveen \& B.Lloyd (Eds.), Social representations and the development of knowledge (pp. 27-46). Cambridge, England: Cambridge University Press.

Liu, L. (2004). Sensitising concept, Themata and Shareness: a dialogical perspective of Social Representations. Journal for the Theory of Social Behaviour, 34, 249-264.

Lotman, J. (1985). La semiosfera. L'asimmetria ed il dialogo nelle strutture pensanti. Venezia: Marsilio.

Manuti, A. (2005). The rhetoric of work flexibility: a diatextual frame of Italian political discourse. Journal of Language and Politics, 4, 371-396.

Markova, I. (2000). Amédée or how to get rid of it: Social Representations from a dialogical perspective. Culture \& Psychology, 6, 419-460.

Markova, I. (2003). Dialogicity and social representations. Cambridge, England: Cambridge University Press.

Mc Combs, M. E., Shaw, D.L., \& Weaver, D. (1997). Communication and Democracy: Exploring the intellectual frontiers in agenda setting theory. Mahwah, NJ: Erlbaum.

Mc Combs, M.E., \& Shaw, D.L. (1972). The agenda setting function of mass media. Public Opinion Quarterly, 36, 176-187.
Mininni, G. (1995). Discorsiva mente. Profilo di psicosemiotica. Napoli, Campania : Edizioni Scientifiche Italiane.

Mininni, G. (2004). Psicologia e media. Bari, BA: Laterza.

Mininni, G. (2003). Il discorso come forma di vita. Napoli, Campania: Guida.

Mininni, G. (2005). Diatexts as a mirror of human complexity. World Futures, 61, 163-175.

Moloney, G., Hall, R., \& Walker, I., (2005). Social Representations and Themata: The construction and functioning of social knowledge about donation and transplantation. British Journal of Social Psychology. 44, 415-441.

Moloney, G., \& Walker, I. (2000). Messiahs, Pariahs, Donors: The development of Social Representations of Organ Transplants. Journal for the Theory of Social Behaviour. 30, 203-227.

Morgan, S., Harrison, T., Long, S., Afifi, W., Stephenson, M., \& Reichert, T. (2005). Family discussions about organ donation: how the media influences opinions about donation decisions. Clinical Transplantation, 19, 674-682.

Moscovici, S. (1961) La psychoanalyse, son image et son public. Paris: Presses Universitaire.

Moscovici, S. (1973). Foreword. In C. Herzlich (Ed.), Health and Illness: A social analysis (pp. IX-XIV). London, England: Academic Press.

Moscovici, S., (1981). On social representations. Perspectives on everyday understanding. In J. Forgas (Ed.), Social Cognition (pp. 181-209). London, England: Academic Press.

Moscovici, S. (1984). The Phenomenon of Social Representation, In R.Farr, \& S.Moscovici (Eds.), Social Representations. Cambridge, England: Cambridge University Press

Moscovici, S. (2001). Why a theory of Social Representations? In K. Deaux \& G. Philogene (Eds.), Representations of the social: Bridging theoretical traditions (pp.8-35). Oxford, England: Blackwell.

Moscovici, S., \& Vignaux, G. (2000). The concept of Themata. In K. Duveen (Ed.) Social Representations. Explorations in Social Psychology (pp. 156-183). Cambridge, England: Polity Press.

Mugny, G., \& Carugati, F. (1989). Social representations of intelligence. Cambridge, England: Cambridge University Press.

Potter, J., \& Litton, I. (1985). Problems underlying the theory of social representations. British Journal of Social Psychology, 24, 81-90.

Potter, J., \& Wetherell, M. (1987) Discourse and Social Psychology. Beyond Attitudes and Behaviour. London, England: Sage.

Potter, J., \& Wetherell, M. (1999). Social Representations and Discursive Psychology: From cognition to action. Culture \& Psychology, 5, 447-458.

Raudsepp, M. (2005). Why is it so difficult to understand the theory of social representations? Culture \& Psychology, 11, 455-468.

Rose, D., Efraim, D., Gervais, M., Joffe, H., Jovchelovitch, S., \& Morant, N. (1995). Questioning consensus in social representation theory. Papers in social representations, 4, 150-176.

Sen, R., \& Wagner, W. (2009). Cultural mechanics of fundamentalism: Religion as ideology, divided identities and violence in post-Gandhi India. Culture \& Psychology, 15, 299-326.

Spaemann R. (1996). Personen. Versuche uber den Unbterschiede zwischen "etwas" und "jemand", Stuttgart: Nachfolger GmbH (tr. it. di L. Allodi, Persone. Sulla differenza tra "qualcosa" $e$ "qualcuno"), Roma-Bari 2005: Laterza.

Spink, M. (1993). Qualitative research on social representations: the delightful world of paradoxes. Papers on Social Representations, 2 , 48-54.

Van Dijk, \& T., A. (1998). Ideology. A multidisciplinary approach. London: Sage.

Van Dijk, \& T., A. (1993). Principles of Critical Discourse Analysis, Discourse \& Society, 4, 249-283.

Van Dijk, \& T., A. (1997). Discourse as Social Interaction, London: Sage.

Voelklein, C., \& Howarth C. (2005). A Review of Controversies about Social Representations Theory: A British Debate, Culture \& Psychology, 11, 431-454.

Volli, U. (2005). Laboratorio di semiotica, Roma-Bari: Laterza. 
Wagner, W. (1995). Description, explanation and method in Social Representation research, Papers on Social Representations, 4, 1-21.

Wagner, W. (1998). Social representations and beyond: brute facts, symbolic coping and domesticated worlds. Culture \& Psychology, 4, 297-329.

Wagner, W., Duveen, G., Farr, R., Jovchelovitch, S., Lorenzi Cioldi, F.,
Markova, I., \& Rose, D. (1999). Theory and Method of Social Representations. Asian Journal of Social Psychology, 2, 95-125.

Wagner, W., Duveen, G., Verma, J., \& Themel, M. (2000). I have some faith and at the same time I don't believe. Cognitive polyphasia and cultural change in India. Journal of Community and Applied Social Psychology, 10, 301-314. 